\title{
Letters
}

\section{Islet autoantibodies at birth in children later developing Type I diabetes mellitus}

\begin{abstract}
Dear Sir,
Interestingly, in the study carried out by Lindberg et al. [1], new evidence was given on the notion that the autoimmune beta-cell aggression that precedes the clinical onset of Type I (insulin-dependent) diabetes mellitus may start in utero. They showed that $17 \%$ of children later developing the disease before the age of 15 years, had circulating autoantibodies against beta-cell antigens during fetal life. It is remarkable, however, that from the data in more than $14 \%$ of the cases one of the parents had Type I diabetes. Being born to a diabetic father or mother confers a higher risk of developing the disease. Furthermore, first-degree relatives of Type I diabetic subjects have a higher prevalence of Type I diabetes-associated autoantibodies. In the above-mentioned study, the authors decided to exclude children of Type I diabetic mothers because of the risk of detecting antibodies transferred by the mother. Neverthe-
\end{abstract}

Corresponding author: D.Mauricio, Unit of Endocrinology and Nutrition, Corporació Sanitària Parc Taulí, Parc Taulí S/N, 08208 Sabadell, Spain less $10 \%$ of the subjects further analysed had a diabetic father. It is not stated in the paper whether islet antibodies were more prevalent in offspring of diabetic fathers. We think it is possibly crucial to know whether there was any association between antibody positivity and parental Type I diabetes. A positive association between both conditions may change the interpretation of the results, since some studies have shown that the so-called 'familial cases' may have a younger onset of the disease compared with 'sporadic cases' [2]. Thus, this could also imply an earlier initiation of autoimmunity in these familial cases.

Yours sincerely,

D. Mauricio, G. Giménez-Pérez

\section{References}

1. Lindberg B, Ivarsson S-A, Landin-Olsson M, Sundkvist G, Svanberg L, Lernmark A (1999) Islet autoantibodies in cord blood from children who developed Type I (insulin-dependent) diabetes mellitus before 15 years of age. Diabetologia 42: 181-187

2. Lorenzen T, Pociot F, Hougaard P, Nerup J (1994) Longterm risk of IDDM in first-degree relatives of patients with IDDM. Diabetologia 37: 321-327

\section{Influence of heredity on the appearance of islet autoantibodies in cordblood from children developing Type I diabetes before 15 years of age}

\begin{abstract}
Dear Sir,
We are grateful for the interest in our article and the opportunity to answer the questions raised by Dr. Mauricio and Dr. Giménez-Pérez on the influence of heredity on the appearance of islet autoantibodies in cordblood from children developing Type I (insulin-dependent) diabetes mellitus before 15 years of age. As stated in the discussion of our paper the majority of children with islet autoantibodies in cordblood did not have a mother or father with Type I diabetes [1]. Dr. Mauricio and Dr. Giménez-Pérez mention that more than $14 \%$ of the children in our study had a parent with Type I diabetes. The $14 \%$ frequency is obtained when the four children who had mothers
\end{abstract}

Corresponding author: B. Lindberg, MD, Department of Paediatrics, Malmö University Hospital, University of Lund, SE20502 Malmö, Sweden
Table 1. Heredity for Type I diabetes and number of islet autoantibody positive subjects

\begin{tabular}{llll}
\hline $\begin{array}{l}\text { Heredity for Type I } \\
\text { diabetes }\end{array}$ & $\begin{array}{l}\text { One } \\
\text { autoanti- } \\
\text { body }\end{array}$ & $\begin{array}{l}\text { Two } \\
\text { autoanti- } \\
\text { bodies }\end{array}$ & $\begin{array}{l}\text { One or two } \\
\text { autoanti- } \\
\text { bodies }\end{array}$ \\
\hline $\begin{array}{l}\text { No heredity } n=72 \\
\text { Mother and Father } n=1^{\text {a }}\end{array}$ & 9 & 3 & 12 \\
Mother $n=3^{\text {a }}$ & 1 & 1 & 1 \\
Father $n=7$ & 2 & 2 & 3 \\
Unknown for Father $n=2$ & 0 & 0 & 2 \\
\hline
\end{tabular}

a excluded from our study

with Type I diabetes are included in the calculation. Our intention was to exclude the children born to mothers with Type I diabetes since the antibodies from the mothers would appear in the cordblood.

In our study, all four children to mothers (see Table 1) with Type I diabetes were autoantibody positive with the mothers having the same autoantibodies. This is in analogy with our previous study of mothers developing Type I diabetes after pregnancy, transferring their autoantibodies to their children [2]. We chose to exclude these four children from our study. 
The complete correlations between heredity and cordblood autoantibodies are presented in Table 1 . Seventeen per cent $(14 / 81)$ of the remaining children had cordblood autoantibodies and 2 of these 14 had fathers with Type I diabetes. The fraction of children with positive islet autoantibodies was greater among children with diabetic fathers; $29 \%(2 / 7)$, than among children without heredity for the disease; $16 \%(12 / 74)$, the difference being non-significant $(p=0.60)$. Paternal heredity for Type I diabetes is still, however, a possible risk factor for early islet cell autoantibodies.

It is worth noting that $16 \%$ of the children later developing Type I diabetes had cordblood autoantibodies against islet cells even in the absence of heredity for the disease among parents.
Yours sincerely,

B. Lindberg, S-A. Ivarsson, Å. Lernmark

\section{References}

1. Lindberg B, Ivarsson S-A, Landin-Olsson M, Sundkvist G, Svanberg L, Lernmark $\AA$ (1999) Islet autoantibodies in cord blood from children who developed Type I diabetes before 15 years of age. Diabetologia 42: 181-187

2. Ivarsson SA, Ackefors M, Carlsson A et al. (1997) Glutamate decarboxylase antibodies in non-diabetic pregnancies precedes insulin-dependent diabetes in the mother but not necessarily in the offspring. Autoimmunity 26: 261-269

\section{Effect of insulin on apolipoprotein(a) synthesis}

\section{Dear Sir,}

Neele et al. have reported that apolipoprotein(a) and apolipoprotein B-100 secretion by cynomolgus monkey hepatocytes is modestly inhibited after incubation with insulin in concentrations ranging from $10^{4}$ to $10^{6} \mathrm{pmol} / \mathrm{l}$ [1]. Such insulin concentrations are approximately 15 to 1500 -fold higher than those measured after a glucose challenge in humans. Nonetheless, they state that an insulin concentration of $10^{4} \mathrm{pmol} / \mathrm{l}$ is low and relevant, considering a half life of insulin about $4 \mathrm{~h}$ under the experimental conditions used. They do not, however, show that this assumption is correct. In comparison, others have shown effects on cholesterol uptake by HepG2 cells and rat hepatocytes when insulin is added in a concentration as low as $600 \mathrm{pmol} / \mathrm{l}$ [2]. Furthermore, they use an enzyme linked immunoassay that measures the apo(a) moiety of lipoprotein(a) [3] and not free apo(a). Since it is most likely that the assembly of lipoprotein(a) is an extracellular event [4], it is possible that the observed decrease in so-called apo(a) is confounded by a decrease in apolipoprotein B-100. Finally, there

Corresponding author: Dr. R.P.F. Dullaart, Department of Endocrinology, University Hospital Groningen, P. O. Box 30.001, Groningen, The Netherlands is no evidence that insulin decreases plasma lipoprotein(a) in healthy humans, despite the lowering of apolipoprotein B-100 synthesis [5]. For these reasons, it is our opinion that the findings of the in vitro study by Neele et al. cannot be extrapolated to the in vivo situation in humans.

Yours sincerely,

S. C. Riemens, R.P.F. Dullaart

\section{References}

1. Neele DM, Wit de ECM, Princen HMG (1999) Insulin suppresses apolipoprotein(a) synthesis by primary cultures of cynomolgus monkey hepatocytes. Diabetologia 42: 41-44

2. Wybranska I, Baczynska E, Cialowicz U, Polus A, Dembinnska-Kiec A (1996) Influence of insulin on cholesterol removal from macrophages and cholesterol ester uptake by HepG2 cells. Eur J Clin Invest 26: 1004-1010

3. Dagen MM, Packard CJ, Shephard J (1991) A comparison of commercial kits for the measurement of lipoprotein(a). Ann Clin Biochem 38: 359-364

4. Frank S, Durovic S, Kostner GM (1996) The assembly of lipoprotein Lp(a). Eur J Clin Invest 26: 109-114

5. Malmström R, Packard CJ, Watson TDG et al (1997) Metabolic basis of hypotriglyceridemic effects of insulin in normal men. Arterioscler Thromb Vasc Biol 17: 1454-1464

\section{Insulin suppresses apolipoprotein(a) synthesis in cultured cynomolgus monkey hepatocytes}

\section{Dear Sir,}

In their comment on our paper which appeared in Diabetologia 42: 41-44 Riemens and Dullaart conclude that the findings of our in vitro study cannot be extrapolated to the in vivo situa-

Corresponding author: Dr H. M. G.Princen, Gaubius Laboratory TNO-PG, P.O.Box 2215, 2301 CE Leiden, The Netherlands tion in humans. We fully agree with this statement and have not attempted to make such an extrapolation in our paper. We just suggested that our findings that insulin suppresses apolipoprotein(a) synthesis in primary cultures of cynomolgus monkey hepatocytes could provide an explanation for the increased plasma concentrations of lipoprotein(a) found in patients with insulin dependent diabetes mellitus and its return to normal after treatment with insulin (as stated clearly in the Summary and in the Discussion). The next step is to prove this in turn-over studies in appropriate experimental animals and in humans.

In studies of the metabolic effects of insulin in cell culture experiments, using hepatocytes from different species, the insulin concentrations applied are usually in the range of 1 to $150 \mathrm{nmol} / \mathrm{l}$. In this context the concentration at which we found 